Microbial Ecology

May 2005; 49 (4): 578 - 589

http://dx.doi.org/10.1007/s00248-004-0093-8

(c) 2005 Springer-Verlag New York, LLC

The original publication is available at http://www.springerlink.com
Archimer http://www.ifremer.fr/docelec/ Archive Institutionnelle de l'Ifremer

\title{
Chemical Characterization of Exopolysaccharides from Antarctic Marine Bacteria
}

\author{
Carol Mancuso Nichols ${ }^{\star^{1}}$, Sandrine Garon Lardière ${ }^{2}$, John P. Bowman ${ }^{3}$, Peter D. Nichols ${ }^{4}$, \\ John A.E. Gibson ${ }^{4}$ and Jean Guézennec ${ }^{2}$
}

(1) School of Agricultural Science, University of Tasmania, Hobart, 7000, Tasmania, Australia

(2) Institut Français de Recherche pour l'Exploitation de la Mer, Center de Brest, Plouzané, France

(3) Australian Food Safety Left, University of Tasmania, Hobart, 7000, Tasmania, Australia

(4) Commonwealth Scientific and Industrial Research Organization, Marine Research, Hobart, 7000, Tasmania,

Australia

(5) Center for Marine Science, University of Tasmania, Hobart, 7000, Tasmania, Australia

*C.A.Mancuso@utas.edu.au Phone: +61 362262642 Fax: +61 362262620

\begin{abstract}
Exopolysaccharides (EPS) may have an important role in the Antarctic marine environment, possibly acting as ligands for trace metal nutrients such as iron or providing cryoprotection for growth at low temperature and high salinity. Ten bacterial strains, isolated from Southern Ocean particulate material or from sea ice, were characterized. Whole cell fatty acid profiles and 16S rRNA gene sequences showed that the isolates included representatives of the genera Pseudoalteromonas, Shewanella, Polaribacter, and Flavobacterium as well as one strain, which constituted a new bacterial genus in the family Flavobacteriaceae. The isolates are, therefore, members of the "Gammaproteobacteria" and Cytophaga-Flexibacter-Bacteroides, the taxonomic groups that have been shown to dominate polar sea ice and seawater microbial communities. Exopolysaccharides produced by Antarctic isolates were characterized. Chemical composition and molecular weight data revealed that these EPS were very diverse, even among six closely related Pseudoalteromonas isolates. Most of the EPS contained charged uronic acid residues; several also contained sulfate groups. Some strain produced unusually large polymers (molecular weight up to $5.7 \mathrm{MDa}$ ) including one strain in which EPS synthesis is stimulated by low temperature. This study represents a first step in the understanding of the role of bacterial EPS in the Antarctic marine environment.
\end{abstract}

Keywords: EPS, Antarctic marine, Trace metal, Nutrients, Bacteria 


\section{CHEMICAL CHARACTERIZATION OF EXOPOLYSACCHARIDES FROM} ANTARCTIC MARINE BACTERIA

Carol Mancuso Nichols ${ }^{1^{\star}}$, Sandrine Garon Lardière ${ }^{2}$, John P. Bowman ${ }^{1}$, Peter D. Nichols ${ }^{3}$, John A.E. Gibson ${ }^{3}$ and Jean Guézennec ${ }^{2}$

1University of Tasmania, Hobart, Tasmania, AUSTRALIA

${ }^{2}$ Institut Français de Recherche pour l'Exploitation de la Mer, Centre de Brest, Plouzané, FRANCE

${ }^{3}$ Commonwealth Scientific and Industrial Research Organization, Marine Research, Hobart, Tasmania, AUSTRALIA

${ }^{*}$ Corresponding author (School of Agricultural Science, GPO Box 252-54, University of Tasmania, Hobart 7000, AUSTRALIA, Phone +61 362262620 , FAX +61 36226 2642, email C.A.Mancuso@utas.edu.au)

\section{ABSTRACT}

Exopolysaccharides (EPS) may have an important role in the Antarctic marine environment, possibly acting as ligands for trace metal nutrients such as iron or providing cryoprotection for growth at low temperature and high salinity. Ten bacterial strains, isolated from Southern Ocean particulate material or from sea ice, were characterized. Whole cell fatty acid profiles and $16 \mathrm{~S}$ rRNA gene sequences showed that the isolates included representatives of the genera Pseudoalteromonas, Shewanella, Polaribacter and Flavobacterium as well as one strain, which constituted a new bacterial genus in the family Flavobacteriaceae. The isolates are, therefore, members 
of the "Gammaproteobacteria" and CFB, the taxonomic groups that have been shown to dominate polar sea ice and seawater microbial communities. EPS produced by Antarctic isolates were characterized. Chemical composition and molecular weight data revealed that these EPS were very diverse, even among six closely related Pseudoalteromonas isolates. Most of the EPS contained charged uronic acid residues; several also contained sulfate groups. Some strains produced unusually large (molecular weight up to $5.7 \mathrm{MDa}$ ) polymers, including one strain in which EPS synthesis is stimulated by low temperature. This study represents a first step in the understanding of the role a bacterial EPS in the Antarctic marine environment.

\section{KEY WORDS}

Exopolysaccharides, Antarctica, marine bacteria, sea ice, marine particulates

\section{RUNNING TITLE}

Characterization of Antarctic bacterial EPS

\section{INTRODUCTION}

Particulate aggregates are ubiquitous and abundant in the world's oceans (Fowler and Knauer 1986). As complex assemblages of zooplankton fecal pellets, phytoplankton and other material enriched in bacteria (Logan and Hunt 1987; Mueller-Niklas et al. 1994), marine aggregates are centers of high bacterial activity and are believed to have a significant role in the downward transport of carbon (Kiorboe 2001). Bacteria in marine aggregates are at an advantage compared to free living cells (Logan and Hunt 1987). 
Their proximity to other cells and surfaces provides opportunities for interaction and nutrient uptake. Exopolysaccharides (EPS) excreted by bacteria are among the polymeric substances that provide a network to hold these structures together (Flemming and Wingender 2001a). Microscopic and laboratory studies have shown that bacterially produced EPS have a major role in aggregate formation (Biddanda 1986, Heissenberger and Herndl 1994; Leppard 1995)

Bacteria contribute significantly to secondary production in sea ice communities and to the overall carbon cycle in the Antarctic environment. In thick pack ice, bacterial secondary production even exceeds primary production as the light supply to the bottom layers of ice is reduced (Grossmann and Dieckmann 1994). Bacteria are found in abundance in the bottom layers of the ice or in brine channels and are often attached to detrital particles or to living microalgal cells (Sullivan and Palmisano 1984, Archer et al. 1996, Delille and Rosier 1996). Delille and Rosier (1996) also suggest that the high numbers of particle associated bacteria found in sea ice may explain observations of underlying water enriched in bacterial biomass relative to the open ocean (Grossmann and Dieckmann 1994). More recently, studies of Arctic sea ice in winter showed that at temperatures as low as $-20^{\circ} \mathrm{C}$, active bacteria were found in the brine channels and were particle associated (Junge et al. 2004). EPS may be providing a cryoprotectant role in these environments of high salinities and low temperature (Krembs et al. 2002). The same authors showed that high concentrations of EPS were found in brine channels and could have been produced by the abundant bacteria or diatom populations present. 
EPS appears to be an integral component of particulate material and sea ice microbial communities, however very little is known about the chemical structures of EPS from cold adapted bacteria or bacteria from Antarctic waters. Basic knowledge of the chemical composition of EPS gives an insight into potential physico-chemical interactions that may take place within or between these polymers or between these polymers and cells or other substances in aquatic environments (Shin et al. 2001, Hirst et al. 2003). Within the polymer, the individual monosaccharides and functional groups covalently linked to them influence the weak cohesive forces that impact on the behavior of these polymers (Decho 1990). Chemical analysis of EPS from specific bacterial members of natural assemblages is difficult due to the low abundance of any one polymer and the complexity of tracing it back to its source (Christensen 1999). Therefore, Antarctic marine bacteria and the EPS they produced in pure liquid cultures were examined in this study as a first step in understanding the ecological significance of these abundant polymers in the Antarctic marine environment.

\section{MATERIALS AND METHODS}

\section{Isolation of bacteria}

Samples were obtained during the November/December 2001 voyage of RSV Aurora Australis and included sea ice and seawater. The geographical position, the type of sample material and the size fraction from which bacterial isolates described in this study were obtained is shown in Table 1. Strains CAM006, CAM030, CAM023, CAM036 were isolated from 
particulate material from the Southern Ocean where the sea temperature was approximately $4^{\circ} \mathrm{C}$ and salinity was $3.5 \%$. CAM005, CAM003, CAM015, CAM025, CAM064, CAM090 were obtained from melted sea ice. Pieces of sea ice (250-500 $\mathrm{ml}$ volume) from the bottom layer of ice floes (containing a visible basal algal band assemblage) were collected with a long handled sieve. Sea ice samples including interstitial seawater were combined with $500 \mathrm{ml}$ sterile artificial seawater $(2.2 \% \mathrm{w} / \mathrm{v}$, Sigma $)$ at $2{ }^{\circ} \mathrm{C}$. Aliquots were plated directly or the samples were stored at $2^{\circ} \mathrm{C}$ for two weeks. This storage temperature was preferable to the alternative $\left(-20^{\circ} \mathrm{C}\right)$ for shipboard storage, as the latter would have caused additional freezing of the core and associated seawater, resulting in dramatically reduced viability of isolates. Upon return to Hobart, aliquots of $200 \mathrm{ml}$ of melted sea ice were passed through a Nucleopore $0.8 \mu \mathrm{m}$ filter placed over a glass fiber filter (Schleicher \& Schuell), which had been preheated to $450^{\circ} \mathrm{C}$ for one hour. The $0.8 \mu \mathrm{m}$ filter or aliquots of $200 \mu \mathrm{l}$ of the filtrate were placed in separate glass McCartney bottles containing $10 \mathrm{ml}$ seawater nutrient broth (SNB, Bowman and Nichols 2002). These enrichment cultures containing medium and filters or medium and filtrate were incubated for $24 \mathrm{hrs}$ at $2^{\circ} \mathrm{C}$, then mixed and $200 \mu \mathrm{l}$ aliquots were removed and spread onto SNAgar (SNB with $12 \mathrm{~g} \mathrm{l}^{-1}$ agar added prior to sterilization) and SNAgar + Glucose $(2 \% \mathrm{w} / \mathrm{v})$. Agar plates were incubated at $4^{\circ} \mathrm{C}$ for four weeks. Additional isolates were obtained from a plankton net (20 $\mu \mathrm{m})$ trawled through the Southern Ocean. Aliquots of $20 \mu \mathrm{l}$ of material from the cod end of the plankton net were spread onto SNAgar and SNAgar + Glucose $(2 \% \mathrm{w} / \mathrm{v})$ and the plates were incubated at $2{ }^{\circ} \mathrm{C}$. 
After initial isolations, strains were subcultured onto marine agar (MA, $1 \mathrm{~g}$ yeast extract, Oxoid L21; $5 \mathrm{~g}$ bacteriological peptone, Oxoid L37; $32 \mathrm{~g}$ artificial sea salts, Sigma S9883; $15 \mathrm{~g}$ agar; $1000 \mathrm{ml}$ distilled water) and MA supplemented with $3 \%(\mathrm{w} / \mathrm{v})$ glucose $(\mathrm{MA}+\mathrm{Glu})$. A glucose solution was prepared and autoclaved separately before being combined with MA. Strains were selected if they displayed a mucoid morphology when grown on $\mathrm{MA}+\mathrm{Glu}$. Approximately 300 isolates demonstrating a mucoid morphology were obtained initially from sea ice and marine particulate samples. The ten strains that showed the best growth on $\mathrm{MA}+\mathrm{Glu}$ at $20^{\circ} \mathrm{C}$ with enhanced mucoid morphology were chosen for further analysis.

\section{Characterization of bacterial isolates}

$16 S$ rDNA gene sequence analyses The 16S rDNA genes of ten strains were amplified by PCR according to procedures described by (Bowman et al. 1996) using DNA primers 10F and 1519R. The PCR products were purified by Prep-A-Gene purification (Bio-Rad, CA, USA) and the concentration of purified DNA in each sample was measured using a Smart Spec 3000 (Bio-Rad, Regent Park, NSW, Australia). Sequences were obtained with a Beckman Coulter CEQ 2000 automated sequencer according to protocol specified by manufacturer (Beckman Coulter, Inc, Fullerton, CA, USA).

Sequences were manipulated and aligned using BioEdit v. 5.0.9 (Hall 1999). Sequences were compared to $16 \mathrm{~S}$ rDNA genes available in the GenBank library by BLAST searching (Atschul et al. 1990) through the National Center for Biotechnology Information (U.S. National Institute of Health) Internet site as described by Bowman et al. (1997). Sequences were 
aligned to their closest related sequences determined from the BLAST searches. PHYLIP (version 3.57c) (Felsenstein 1993) was used to analyse the sequence data and sequence similarities with the maximum likelihood algorithm option were determined using DNADIST. Phylogenetic trees were constructed by the neighborliness method with the program NEIGHBOR. The sequence for Escherichia coli (J01695) was included as an outgroup. Partial sequences for the ten isolates were deposited into GenBank under accession numbers: AY243365, AY243366 and AY586522 to AY586529.

\section{Whole-cell fatty acid analyses}

Growth conditions were the same for all strains so that whole cell fatty acid profiles could be compared. The ten isolates were grown on MA at $12^{\circ} \mathrm{C}$ for four weeks. This incubation temperature was chosen as it approximates a median growth temperature for Antarctic sea ice bacteria (Bowman et al. 1997a). Whole cell fatty acids were extracted from cell material according the MIDI protocol (Sasser 1990). Fatty acid methyl esters (FAME) were treated with N,O-bis-(trimethylsilyl)-trifluoroacetamide to convert hydroxy acids to their corresponding trimethylsilyl (TMSi) ethers for analysis by gas chromatography (GC) and GC-mass spectrometry. Double bond position and geometry of monounsaturated FAME for selected strains were determined after the formation of dimethyl-disulfide (DMDS) adducts prepared according to methods described previously (Nichols et al. 1986).

GC analyses were performed on a Hewlett Packard 5890A GC fitted with an HP-5 cross-linked methyl silicone fused capillary column (50 m X 0.32 mm i.d.) and flame ionization detector (FID, $310^{\circ} \mathrm{C}$ ) and an HP 7673A auto sampler. Helium was the carrier gas. Samples were injected in splitless 
mode at an oven temperature of $50^{\circ} \mathrm{C}$. After one minute, the oven temperature was raised to $150^{\circ} \mathrm{C}$ at $30^{\circ} \mathrm{C} \mathrm{min}{ }^{-1}$ then to $250^{\circ} \mathrm{C}$ at $2^{\circ} \mathrm{C} \mathrm{min}$ and finally to $300^{\circ} \mathrm{C}$ at $5^{\circ} \mathrm{C} \mathrm{min}^{-1}$. GC-MS analyses of the FAME were performed using a Finnigan GCQ Plus GC/MS system fitted with on-column injection set at $45^{\circ} \mathrm{C}$. Samples were injected using an AS2000 auto sampler into a retention gap attached to a HP 5 Ultra 2, (50 m X $0.32 \mathrm{~mm}$ i.d., and $0.17 \mu \mathrm{m}$ film thickness column using helium for the carrier gas. The chromatograms and mass spectra were analysed using Excalibur software. Peaks were identified by comparison to known and laboratory standards, the library included with the software, and by consideration of the mass spectra.

Fatty acids are designated by the total number of carbon atoms:number of double bonds, followed by the position of the double bond from the terminal $(\omega)$ end of the molecule. The suffixes $\mathrm{c}$ and $\mathrm{t}$ indicate cis and trans geometry and the prefixes $i$ and a indicate iso and anteiso branching. The position of hydroxyl group $(\mathrm{OH})$ may occur on the second $(\alpha)$ or third $(\beta)$ carbon from the carboxyl end of the molecule

\section{EPS production and characterization analyses}

\section{Growth of Antarctic isolates in batch cultures for EPS production}

A McCartney bottle containing $20 \mathrm{ml}$ marine broth supplemented with 3 $\%(w / v)$ glucose $(M B+G l u)$ was inoculated with approximately ten colonies of each strain from an agar plate (MA+Glu) inoculated ten days earlier and incubated at $20^{\circ} \mathrm{C}$. This incubation temperature was chosen after growth on solid media $(\mathrm{MA}+\mathrm{Glu})$ demonstrated that this was the maximum temperature at which all strains achieved good growth. The $20 \mathrm{ml}$ cultures were shaken 
for $24 \mathrm{hr}(200 \mathrm{rpm})$ at $20^{\circ} \mathrm{C}$. These cultures were used to inoculate $200 \mathrm{ml}$ of the same media and the resulting culture was shaken (200 rpm) and incubated at $20^{\circ} \mathrm{C}$. After $48 \mathrm{hr}$, this broth was checked for contamination by subculturing onto a MA+Glu plate and a $10 \mathrm{ml}$ aliquot was removed to measure $\mathrm{pH}$. The remaining broth was used to inoculate $500 \mathrm{ml} \mathrm{MB}+\mathrm{Glu}(\mathrm{pH}$ 7) in a 2 I Schott bottle.

This $500 \mathrm{ml}$ broth culture was bubbled with compressed air (138 kPa). Inlet and outlet air was filtered through a $0.2 \mu \mathrm{m}$ Midisart filter (Sartorius Australia Pty. Ltd, VIC). Broth cultures were shaken (150 rpm) at $20^{\circ} \mathrm{C}$ for one week. Subculturing onto MA+Glu was used to check for contamination.

\section{Isolation and purification of bacterial EPS}

EPS were harvested according to procedures described previously (Mancuso Nichols et al. 2004). Briefly, culture broths were centrifuged at $30000 \mathrm{~g}$ for $2 \mathrm{hr}$ at $4^{\circ} \mathrm{C}$ and the supernatants were pressure filtered through cellulose nitrate filters (Sartorius Australia Pty. Ltd., VIC). EPS were precipitated from the final filtrate after the addition of cold ethanol and the resulting precipitates were washed with $70 \%$ to $100 \%$ ethanol - water mixtures. The EPS were dried in a desiccator and stored at room temperature. To remove excess salts, the EPS were redissolved in distilled water and dialyzed (molecular weight cut off of $0.1 \mathrm{MDa}$, Spectra/Por, Spectrum Laboratories, CA, USA) against distilled water for 2 days at room temperature (approx $25^{\circ} \mathrm{C}$ ). Excess water was removed under vacuum before lyophilization. The EPS were stored at room temperature until analysis. 


\section{EPS Characterization}

\section{Colorimetric Analyses}

Uronic acid content of the EPS was determined by the metahydroxydiphenyl method (Blumenkrantz and Asboe-Hansen 1973; FilisettiCozzi and Carpita 1991). Protein content was determined by the Lowry protein assay (Lowry et al. 1951) with bovine serum albumin as the standard. The total neutral carbohydrate content was determined by the orcinol-sulfuric acid method modified by Rimington (1931).

\section{FT-IR Spectroscopy}

Pellets for infrared analysis were prepared by grinding a mixture of 2 mg polysaccharide with $200 \mathrm{mg}$ dry $\mathrm{KBr}$, followed by pressing the mixture into a $16 \mathrm{~mm}$ diameter mold. The Fourier transform-infrared (FT-IR) spectra were recorded on a Bruker Vector 22 instrument with a resolution of $4 \mathrm{~cm}^{-1}$ in the $4000-400 \mathrm{~cm}^{-1}$ region. Approximate sulfate content was determined by FT-IR spectroscopy according to the method of Lijour et al. (1994).

\section{Monosaccharide analyses}

To a solution containing $250 \mu \mathrm{g}$ total EPS, $50 \mu \mathrm{g}$ erythritol was added as an internal standard. Samples for GC analyses were prepared in triplicate and freeze-dried. The polymer was hydrolysed by the addition of methanolic $\mathrm{HCl}\left(3 \mathrm{~N}\right.$, Supelco, PA, USA) and heating for $16 \mathrm{hr}$ at $80^{\circ} \mathrm{C}$ (Kamerling et al. 1975, modified by Montreuil et al. 1986). The monosaccharides were converted to their TMSi derivatives by the addition of Bis(trimethylsilyl)trifluoroacetamide:trimethylchlorosilane / 99:1 (Supelco, PA, 
USA) and pyridine. The samples were held at room temperature for $2 \mathrm{hr}$, then dried under nitrogen and redissolved in dichloromethane prior to analyses.

\section{Gas Chromatography}

Analyses of the monosaccharides as trimethylsilyl derivatives were performed on a GC8000 (Fisons, Paris, France) GC fitted with an automatic injector, an FID $\left(300^{\circ} \mathrm{C}\right)$ and a CP-Sil-5CB glass capillary column $(0.32 \mathrm{~mm} \mathrm{X}$ $60 \mathrm{~m}$, Chrompac, Varian, France). Hydrogen was the carrier gas. The GC oven was temperature programmed as follows: $50^{\circ} \mathrm{C}$ for $1 \mathrm{~min}$ then an increase of $20^{\circ} \mathrm{C} / \mathrm{min}$ until $120^{\circ} \mathrm{C}$, followed by a gradient of $2^{\circ} \mathrm{C} / \mathrm{min}$ until $240^{\circ} \mathrm{C}$.

\section{Size exclusion chromatography}

Molecular weights of EPS were determined by size exclusion chromatography (SEC). The eluant was a $0.1 \mathrm{M} \mathrm{NaNO}_{3}$ in water with $0.02 \%(\mathrm{w} / \mathrm{v})$ sodium azide added. The analyses were carried out at room temperature. An isocratic pump (Spectra Physics P100, Thermo Separations, Bordeaux, France) with a flow rate of $1 \mathrm{ml} \mathrm{min}^{-1}$ and a TSK gel PW6000 column (Toyo Haas, Frankfurt, Germany) was used $(60 \mathrm{~cm} \times 0.7 \mathrm{~cm})$ with pectin as a standard. For detection, a differential refractometer (Shodex RI71, Shodex, Tokyo, Japan) and a multiangle light scattering detector described elsewhere (Busnel et al. 1995) were employed. The polydispersity $\left(I_{p}\right)$ is the ratio of the molecular weights based on the weight of the molecules $\left(\mathrm{M}_{\mathrm{w}}\right)$ to the molecular weight based on the number of molecules $\left(M_{n}\right)$, relative to the pectine standard $\left(M_{w} / M_{n}=I_{p}\right)$. 


\section{RESULTS}

\section{Isolation and characterization of bacteria}

Several hundred isolates from sea ice and particulate material displayed mucoid morphology at $2^{\circ} \mathrm{C}$ on media with added glucose. Due to time constraints, the ten isolates that showed the best growth and enhanced mucoid morphology on $\mathrm{MA}+\mathrm{Glu}$, relative to $\mathrm{MA}$ at $20^{\circ} \mathrm{C}$ were selected for further characterization. All ten isolates were Gram-negative rods and showed growth in the temperature range of $4^{\circ} \mathrm{C}$ to $20^{\circ} \mathrm{C}$. All isolates except CAM030 also displayed good growth and mucoid morphologies on MA+Glu after one week at $25^{\circ} \mathrm{C}$. None of the strains was able to grow at $37^{\circ} \mathrm{C}$. These isolates therefore, appear to be psychrotolerant.

According to $16 \mathrm{~S}$ rRNA sequencing results, the ten isolates belonged to the order Alteromonadaceae (Figure 1) and the family Flavobacteriaceae (Figure 2). CAM003, CAM015, CAM023, CAM025, CAM036 and CAM064 were closely related and grouped in a sub-branch of the genus Pseudoalteromonas in which many Antarctic strains are found (Bowman 1998). The fatty acid profiles for these six Pseudoalteromonas isolates were consistent with the 16S rRNA identifications and are supported by other studies (Bozal et al. 1997; Bowman 1998, Table 2). Based on 16S rDNA data, CAM090 was most similar to Shewanella livingstonensis (Figure 1Bozal et al. 2002Bozal et al. 2002Bozal et al. 2002). The whole cell fatty acid profile of CAM090 was very similar to that presented by Bozal et al. (2002) for Shewanella livingstonensis and included $\mathrm{i} 13: 0$ and $16: 1 \omega 7 \mathrm{c}$ as the most abundant whole cell fatty acids. The whole cell fatty acid profiles for 
CAM003, CAM015, CAM023, CAM025, CAM036 and CAM064 showed many similarities to that of CAM090 (Table 2). As the genera Pseudoalteromonas and Shewanella belong to the order Alteromonas, these seven isolates are therefore members of the class, "Gammaproteobacteria".

CAM006 was identified by $16 \mathrm{~S}$ rDNA sequencing as being closely related to Polaribacter irgensii (Gosink et al. 1998) and CAM005 was related to Flavobacterium frigidarium (Humphry et al. 2001). Strain CAM030 was distant from validly described species within family Flavobacteriaceae and was most closely related to the species Myroides odoratus (Gherna and Woese 1992; Vancanneyt et al. 1996, Figure 2). As a group, CAM005, CAM006 and CAM030 had whole cell fatty acid profiles typical of the Cytophaga-Flexibacter-Bacteriodes (CFB) phylum, and were dominated by

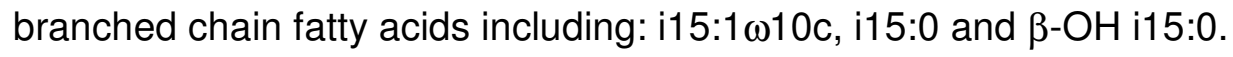
Differences were apparent between the whole cell fatty acid profiles of the three strains (Table 2). A study by Gosink et al. (1998) showed that $\beta-\mathrm{OH}$ i15:0 was the most abundant (38\%) whole cell fatty acid in Polaribacter irigensii. We found $\beta-\mathrm{OH}$ i15:0 present at $20 \%$ of the total fatty acids and i15:0 (15\%) as the second most abundant whole cell fatty acid in CAM006 and this was in agreement with the earlier findings. In a study by Bernardet et al. (1996) the most abundant whole cell fatty acids of Flavobacterium species were reported and are consistent with the whole cell fatty acid profile of Flavobacterium odoratus (since renamed as Myroides odoratus) and were identified as: i15:0 (39\%), $\beta-\mathrm{OH}$ i17:0 (9\%). These were also abundant in CAM030: i15:0 (19\%), $\beta-\mathrm{OH}$ i17:0 (4\%). There were many minor whole cell fatty acids common between the strains, however, one obvious difference 
was the presence in large amounts of $115: 1 \omega 10 \mathrm{c}$ in CAM030 (22\%) and in the other Flavobacterium species reported in this study but the absence of this fatty acid in Myroides odoratus. As $16 \mathrm{~S}$ rRNA sequencing results showed that CAM030 was more closely related to Myroides odoratus than to any of the other genera in the Flavobacteriaceae family, further work is necessary to identify this Antarctic marine isolate. Phylogenetically these three isolates, as members of family Flavobacteriaceae, are also part of the larger CFB phylum.

\section{Chemical characterization of EPS}

Figure 3 shows the approximate contribution of neutral sugars, uronic acids, amino sugars, sulfates and proteins to the EPS produced by each strain. Data are reported as percentages of the total EPS on a weight basis. Neutral sugars accounted for nearly half of all ten EPS. Uronic acids made up the second most abundant fraction of EPS from CAM030, CAM023, CAM025, CAM036, CAM064 and CAM090. Protein was a major component of EPS from CAM005, CAM006 and CAM015. The protein content in EPS from CAM005, CAM006 was $40 \%$ and $50 \%$ respectively. Purification of these EPS included high-speed centrifugation, followed by pressure filtration, dialysis (0.1 MDa cut-off) and ethanol precipitation. These steps were expected to have removed cellular material and unbound proteins, which would have otherwise contributed to elevated protein levels. The protein in these EPS may be bound to the polysaccharide and further analyses are required to better understand these structures. FT-IR analyses showed EPS from CAM003 to have approximately $15 \%$ sulfate, while EPS of strains CAM025, CAM036 and CAM064 contained lower percentages of sulfate. 
Amino sugars were present in EPS from several strains as determined by GC analysis (Figure 3).

The abundances of monosaccharide components in EPS produced by each isolate were presented as percentage of total monosaccharides (Table 3). Mannose represented the most abundant neutral sugar in the EPS, especially in the EPS of strains CAM003, CAM005, CAM030, CAM006, CAM064 and CAM090. Pseudoalteromonas sp. CAM003 contained high percentages of both fucose and mannose while closely related strains CAM023 and CAM025, by contrast, included glucose as the most abundant neutral sugar. Pseudoalteromonas sp. CAM036 contained mannose and glucose as well as galacturonic acid in nearly equal amounts, on a percentage basis. The amino sugars, $\mathrm{N}$-acetyl galactosamine and $\mathrm{N}$-acetyl glucosamine, were present in high amounts in CAM030 (approximately 10\%). $\mathrm{N}$-acetyl galactosamine was also present in CAM036 and CAM064 at 14 and $11 \%$ respectively (Table 3 ).

Average molecular weights of EPS are presented in Table 4. Polydispersity gives an indication of the molecular weight distribution or range of size homogeneity within each polymer. As polydispersity increases, there is a larger difference between the sizes of the largest molecules and the smallest molecules. All polymers in this study had a polydispersity below 2.5 based on the molecular weight measurements. This data indicates that for each EPS analysed, only one polymer was present and this polymer was relatively homogeneous with respect to molecular weight.

The EPS produced by strains CAM003, CAM005, CAM006, CAM015, CAM023, CAM025 and CAM036 had molecular weights greater than 1.7 
MDa. CAM030, CAM064 and CAM090 produced EPS with molecular weights less than $0.2 \mathrm{MDa}$. Molecular weight measurements also indicated a wide range in the average molecular weight of EPS produced by the Antarctic marine isolates examined in this study. Large differences were apparent between the EPS produced by the closely related strains CAM025 and CAM064, with CAM025 producing the EPS with the highest molecular weight (5.7 MDa) and CAM064 producing one of the smallest (0.1 MDa).

\section{DISCUSSION}

\section{Characterization of bacteria}

Studies of the diversity of polar sea ice and seawater microbial communities have shown that the "Gammaproteobacteria" and CFBs are the dominant taxonomic groupings generally found in this environment as determined by cultivation and non-cultivation dependant techniques (Bowman et al. 1997b; Simon et al. 1999; Staley and Gosink 1999; Brinkmeyer et al. 2003). The ten Antarctic marine bacterial isolates examined in this study belong to these phylogenetic groups as demonstrated by results from $16 \mathrm{~S}$ rDNA sequencing and whole cell fatty acid analysis. Our data also indicated that six of the ten strains investigated were in a clade within the genus Pseudoalteromonas particularly common in the Southern Ocean, especially in sea ice (Bowman 1998).

\section{Characterization of EPS}

The EPS produced by the ten Antarctic strains were diverse with respect to crude chemical (Figure 3) and monosaccharide (Table 3) 
composition. In a study of Pseudomonas antarctica, $\mathrm{NF}_{3}$, (Bozal et al. 1994, Bozal et al. 1997), crude chemical analysis of exopolymers produced by this strain showed a high protein content, while individual monosaccharide data were not presented. Capsular material, generally high in proteins (Kenne and Lindberg 1983), was included in the fraction analysed in this earlier study. As our study examines EPS excreted into the media, comparison of these two data sets is not possible. A study by Corsaro et al. (2004) examined the exopolymers produced by another Antarctic marine isolate, Pseudomonas haloplanktis TAC 125, and showed the polysaccharide component to consist of mannose with traces of glucose. Since the fraction examined in this study also included the LPS layer, it is not possible to compare these results with those of our study. Excreted EPS produced by non-marine strains was analysed in a study by Ford et al. (1991). Uronic acids made up less that $1 \%$ of the total carbohydrates. This is significantly lower than the uronic content of the EPS examined in the current study.

The EPS produced by several deep-sea hydrothermal vent bacterial isolates have been well characterized (Rougeaux et al. 1996), including two from genus Pseudoalteromnas. Despite the strains belonging to two different species, the EPS produced by these deep-sea isolates were very similar with respect to crude chemical and monosaccharide composition. These results contrast with those presented in a previous study (Mancuso Nichols et al. 2004) and this one, in which EPS produced by closely related strains in the genus Pseudoalteromonas vary substantially. Sulfate content was noted as the only structural difference between the polymers in the two hydrothermal vent strains and sulfate content may have had an influence on the intrinsic 
viscosity of these polymers since it also varied. Another study found two closely related hydrothermal vent bacteria from different subspecies of Alteromonas macleodii, and isolated from different sites, produced very different EPS under the same growth conditions (Cambon-Bonavita et al. 2002). These EPS show a high metal binding capacity (Loaec et al. 1998). This quality has been attributed to chemical characteristic also present in the EPS produced by the Antarctic marine isolates examined in this study, including carboxyl groups present in uronic acids, amides present in amino sugars, sulfates and to a lesser extent to hydroxyl groups, which are abundant in all monosaccharides. These EPS are thought to aid in attaching bacteria to the hydrothermal chimney as well as lowering the concentrations of toxic heavy metals in the microenvironment.

Monosaccharide analyses of the ten EPS examined in this study showed that pentoses (ribose and xylose), hexoses (glucose, galactose, mannose, rhamnose and fucose), amino sugars ( $\mathrm{N}$-acetyl glucosamine, $\mathrm{N}$ acetyl galactosamine) and uronic acids (glucuronic acid and galacturonic acid) were present, with glucose, galactose or mannose being the most abundant monosaccharides. These sugars are typically found in bacterial EPS (Kenne and Lindberg 1983). A survey of EPS produced by pure cultures of seawater isolates by Kennedy and Sutherland (1987) shows that this is also the case for EPS produced by marine bacteria. Arabinose was present, to varying degrees, in all EPS examined in this study and xylose was present as a minor component in CAM030, CAM090 and CAM090. Arabinose and xylose are not commonly found in bacterial EPS (Kenne and Lindberg 1983). The significance of these finding requires further investigation. 


\section{The ecological role of EPS}

In both sea ice and marine particulate material, bacteria are seen as an integral part of the trophodynamics and are credited with a critical importance in the organic carbon cycle (Grossmann and Dieckmann 1994; Azam 1998). Bacterial polysaccharides form the fibrillar frame work, act as glue in the ultrastructure and provide the structural network for microbial associations within marine aggregates (Flemming and Wingender 2001a, Biddanda 1986; Heissenberger et al. 1996, Decho and Herndl 1995). Studies of sea ice microbial communities also have found bacteria to be strongly particle associated (Sullivan and Palmisano 1984, Grossi et al. 1984). More recent results showed that microbial EPS was produced in high concentrations and it was suggested that it played an important role in cryoprotection (Krembs et al. 2002, Junge et al. 2004).

Exopolymers produced by marine bacteria generally contain $20-50 \%$ of the polysaccharide as uronic acid (Kennedy and Sutherland 1987). Uronic acids contain an acidic carboxyl group that is ionisable at seawater $\mathrm{pH}$. This contributes a negative charge to the overall polymer (Decho 1990). Sulfate was thought to occur only in polysaccharides produced by Archaea and Cyanobacteria until recently, and its presence in polymers produced by prokaryotes is seen as very uncommon (Arias et al. 2003). When sulfate is present as a functional group, it also contributes to the anionic quality of these EPS in seawater (Leppard et al. 1996). The overall negative charge gives the molecule a 'sticky' quality. This 'stickiness' is important in terms of the affinity of these EPS for binding to cations such as dissolved metals (Brown and Lester 1982). Based on the data presented, the EPS from our isolates, which 
contain uronic acids as well as sulfates, would be in a highly polyanionic state in the marine environment.

The availability of iron $\left(\mathrm{Fe}^{+3}\right)$ as a trace metal is of critical importance in the Southern Ocean where it is know to limit primary production (Scharek et al. 1997). As much as $99 \%$ of dissolved iron in the ocean is bound to organic ligands (Wu et al. 2001). Our results indicate that several of the EPS produced by Antarctic bacterial isolates derived from Southern Ocean particulate material included uronic acids and/or sulfates (CAM030, CAM006, CAM23 and CAM036, Figure 3). These EPS may be acting as ligands for cations such as iron and other trace metals in the Southern Ocean environment. A study of Arctic sea ice demonstrated that photosynthesis rates by phytoplankton from under the ice were stimulated to similar levels by sea ice extracts as they were by the chelator, ethylenediamine tetra-acetic acid and trace metals (Apollonio et al. 2002). From those results, the authors suggested that a natural 'conditioning agent' is produced within the bottom-ice algal layer that enhances phytoplankton growth. Sea ice bacterial communities and high amounts of EPS are concentrated in these layers (Krembs and Engel 2001; Krembs et al. 2002). It is not clear whether dissolved iron is a limiting nutrient for primary production in sea ice microbial communities. Isolates derived from pack ice (CAM003 and CAM025) or from fast ice (CAM005, CAM064 and CAM090) produced EPS containing uronic acids and/or sulfates. These EPS would be negatively charged in the marine environment and could possibly have some role in enhancing primary production. The overall significance of this finding requires further investigation 
EPS produced by sea ice isolates CAM003, CAM005 and CAM025 were shown, by molecular weight analysis to be 1.8, 1.8 and 5.7 MDa, respectively. Most exopolysaccharides produced by marine bacteria have a molecular weight in the 0.1-0.3 MDa range (Decho 1990), therefore the EPS produced in liquid culture by three sea ice isolates examined in this study are between 5 and 50 times larger than average. The structure and properties of EPS are influenced by the length of the polymer chain, that is, the molecular weight (Christensen 1999). As the length of the polymer increases, there is a greater the opportunity for complex entanglement the chains and intramolecular associations, and these contribute to the tertiary structure and physical behavior of the polymer (Sutherland 1994). A fungal strain, Phoma herbarum, isolated from Antarctic soil produced a homosaccharide of glucose with a molecular weight of 7.4 MDa (Selbmann et al. 2002). The authors of this study suggested the fungal EPS could provide a cryoprotective role in the harsh Antarctic environment where the availability of liquid water and temperatures are extremely low. Similarly, the freezing processes in sea ice result in brine channels where temperature is very low and salinity is high due to brine. Strain CAM025 was observed to produce 30 times as much EPS at -2 and $10^{\circ} \mathrm{C}$ compared to $20^{\circ} \mathrm{C}$ (Mancuso Nichols et al. 2004). Whether this increased EPS production at low temperature is a cold adaptation mechanism for this strain, requires further investigation. Bacterial EPS production in brine channels and perhaps other cold, high brine ecosystems may provide a barrier against the environmental extremes experienced by the bacterial cell by modifying water properties near the cell. 
An exopolysaccharide, known as muran, is produced by the halophilic bacterium, Halomonas maura (Arias et al. 2003). When this strain was grown in media containing high salt concentration $(2.5 \%, \mathrm{w} / \mathrm{v})$, it produces a high molecular weight (4.5 MDa) EPS that contained glucose, mannose and galactose as well as high amounts of glucuronic acid (8\%,w/w) and sulfates $(6.5 \%, \mathrm{w} / \mathrm{w})$. This polysaccharide was able to bind a range of heavy metal cations. The authors also noted the stability of muran under different stress conditions including high salt concentrations and during freezing/thawing. There are similarities between muran and several of the EPS produced by our Antarctic marine isolates in terms of chemical composition. Further work is necessary to more accurately define the structure of the Antarctic marine bacterial EPS and to relate these findings to the function of these molecules in the natural environment. As yet, it is unclear how these polysaccharides may be acting mechanistically as organic ligands, protectants against low temperature or high salinity, or whether the size of these EPS is related to their ecological role.

\section{Biotechnological potential}

Polysaccharides with biotechnological potential have been derived from bacteria isolated from extreme environments such as hydrothermal vents and hypersaline habitats as mentioned above. Because of their physico-chemical properties, which include stabilizing, thickening, gelling, coagulating, adhesion and water retention, bacterial EPS have been used in many commercial applications for example in the pharmaceutical, food and environmental industries (Guézennec 2000; Flemming and Wingender 2001b, Sutherland 1998). EPS produced by Antarctic bacteria examined in the 
current study appear to be diverse with respect to chemical composition. These EPS also share chemical characteristics such as high uronic acid content, sulfate content and molecular weight found in polysaccharides that have been exploited commercially. A better understanding of the chemical structure of these complex molecules is the first step in the discovery of potential biotechnological uses as well as their role in the Antarctic marine environment.

\section{CONCLUSIONS}

Bacteria living in Antarctic sea ice and particulate material in the Southern Ocean experience extreme ecological pressures. EPS is produced by many marine bacteria isolated from this environment. This study is a first step towards understanding the role of these substances in the Antarctic marine environment. A set of ten isolates were found to belong to the "Gammaproteobacteria" and CFBs, which are dominant taxonomic groups in this environment. Study of the chemical composition of EPS produced by these isolates shows that there are distinct differences in terms of crude chemical composition, size and monosaccharide content, even for those EPS produced by closely related strains. Whether the specific ecological role for these bacterial EPS includes cryoprotection in the high salinity, low temperature brine channels in sea ice, or trace metal binding in marine aggregates remains to be elucidated. Increased knowledge of the role of Antarctic bacterial EPS will also provide insight into possible commercial uses for these novel polymers. 


\section{ACKNOWLEDGEMENTS}

The authors thank Jenny Skerratt and Andrew Pankowski for sample collection. Andrew Bissett and Guy Abell from the School of Agricultural Science at the University of Tasmania are acknowledged for assistance in the molecular laboratory. Molecular weight analyses were performed by Mr J.P. Busnel in the Department of Polymers, Colloids and Interfaces at the Université du Maine, France. Gerard Raguénès of IFREMER Centre de Brest is also thanked for his assistance in the microbiology laboratory. Danny Holdsworth managed the CSIRO GC-MS facility. The authors also wish to thank Dr Jim Fredrickson and three anonymous reviewers whose comments improved this manuscript. CMN was supported by a Tasmanian Postgraduate Research Scholarship and by funding provided by the Australian Antarctic Division. CMN also received a travel award from the Australian Academy of Science and the French Embassy in Canberra, Australia. 


\section{REFERENCES}

Apollonio S, Pennington M, Cota GF (2002) Stimulation of phytoplankton photosynthesis by bottom-ice extracts in the Arctic. Polar Biol 25: 350-354

Archer SD, Leakey RJG, Burkill PH, Sleigh MA, Appleby CJ (1996) Microbial ecology of sea ice at a coastal Antarctic site: community composition, biomass and temporal change. Mar Ecol-Prog Ser 135: 179-195

Arias S, del Moral A, Ferrer MR, Tallon R, Quesada E, Béjar V (2003) Mauran, an exopolysaccharide produced by the halophilic bacterium Halomonas maura, with a novel composition and interesting properties for biotechnology. Extremophiles 7: 319-326

Atschul SF, Gish W, Miller W, Myers EW, Lipman EJ (1990) Basic local alignment search tool. J Microbiol Biotechn 215: 403-410

Azam F (1998) Microbial control of oceanic carbon flux. Science 280: 694-696

Bernardet J-F, Segers P, Vancanneyt M, Berthe F, Kersters K, Vandamme P (1996) Cutting the gordian knot: Emended classification and description of the genus Flavobacterium, emended description of the Family Flavobacteriaceae, and proposal of the Flavobacterium hydatis nom.nov. (Basonym, Cytophaga aquatiltis Strohl and Tait 1978). Int J Syst Bacteriol 46: $128-148$

Biddanda BA (1986) Structure and function of microbial aggregates. Oceanol Acta 9: 209-211

Blumenkrantz N, Asboe-Hansen G (1973) New method for quantitative determination of uronic acids. Anal Biochem 54: 484-489

Bowman JP (1998) Pseudoalteromonas prydzensis sp. nov., a psychrotrophic, halotolerant bacterium from Antarctic sea ice. Int J Syst Bacteriol 48: 1037-1041

Bowman JP, Brown MV, Nichols DS (1997a) Biodiversity and ecophysiology of bacteria associated with Antarctic sea ice. Antarct Sci 9: 134-142

Bowman JP, Cavanagh J, Austin JJ, Sanderson K (1996) Novel Psychrobacter species from Antarctic ornithogenic soils. Int J Syst Bacteriol 46: 841-848

Bowman JP, McCammon SA, Brown MV, Nichols DS, McMeekin TA (1997b) Diversity and association of psychrophilic bacteria in Antarctic sea ice. Appl Environ Microbiol 63: 3068-3078

Bowman JP, Nichols DS (2002) Aequorivita gen. nov., a member of the family Flavobacteriaceae isolated from terrestrial and marine Antarctic habitats. Int $\mathrm{J}$ Syst Evol Micro 52: 1533-1541 
Bozal N, Manresa A, Castellvi J, Guinea J (1994) A new bacterial strain of Antarctica, Alteromonas sp. that produces a heteropolymer slime. Polar Biol 14: $561-567$

Bozal N, Montes MJ, Tudela E, Jimenez F, Guinea J (2002) Shewanella frigidimarina and Shewanella livingstonensis $\mathrm{sp}$ nov isolated from Antarctic coastal areas. Int J Syst Evol Micro 52: 195-205

Bozal N, Tudela E, Rossello-Mora R, Lalucat J, Guinea J (1997)

Pseudoalteromonas antarctica sp. nov., isolated from an Antarctic coastal environment. Int J Syst Bacteriol 47: 345-351

Brinkmeyer R, Knittel K, Jurgens J, Weyland H, Amann R, Helmke E (2003) Diversity and structure of bacterial communities in Arctic versus Antarctic pack ice. Appl Environ Microbiol 69: 6610-6619

Brown MV, Lester JN (1982) Role of bacterial extracellular polymers in metal uptake in pure bacterial culture and activated sludge - I. Water Res 16: 15391548

Busnel J, Degoulet C, Nicolai T, Woodley W, Patin P (1995) Multiangle light scattering angle and viscosimetric detector for size-exclusion chromatography. J Phys III France 5: 1501-1512

Cambon-Bonavita M-A, Raguénès G, Jean J, Vincent P, Guézennec J (2002) A novel polymer produced by a bacterium isolated from a deep-sea hydrothermal vent polychaete annelid. J Appl Microbiol 93: 310-315

Christensen BE (1999) Physical and chemical properties of extracellular polysaccharides associated with biofilms and related substances. In: Wingender J, Neu T, R., Flemming HC (eds) Microbial Extracellular Substances - characterization, structure and function. Springer, New York, pp 144-154

Corsaro MM, Lanzetta R, Parrilli E, Parrilli M, Tutino ML, Ummarino S (2004) Influence of growth temperature on lipid and phosphate contents of surface polysaccharides from the Antarctic bacterium Pseudoalteromonas haloplanktis TAC 125. J Bacteriol 186: 29-34

Decho AW (1990) Microbial exopolymer secretions in ocean environments: their role(s) in food webs and marine processes. In: Barnes M (ed) Oceanogr Mar Biol Annu Rev. Aberdeen Univ Press, Aberdeen, pp 73-153

Decho AW, Herndl GJ (1995) Microbial Activities and the transformation of organic matter within mucilaginous material. Sci Total Environ 165: 33-42

Delille D, Rosier C (1996) Seasonal changes of Antarctic marine bacterioplankton and sea ice bacterial assemblages. Polar Biology 16: 27-34

Felsenstein J (1993) PHYLIP (phylogeny inference package), version 3.57c. University of Washington, Seattle, Washington 
Filisetti-Cozzi TMCC, Carpita NC (1991) Measurement of uronic acid without interference of neutral sugars. Anal Biochem 197: 157-162

Flemming HC, Wingender $\mathrm{J}$ (2001a) Relevance of microbial extracellular polymeric substances (EPSs) - Part I: Structural and ecological aspects. Water Sci Technol 43: 1-8

Flemming HC, Wingender $\mathrm{J}$ (2001b) Relevance of microbial extracellular polymeric substances (EPSs) - Part II: Technical aspects. Water Sci Technol 43: $9-16$

Ford T, Sacco E, Black J, Kelley T, Goodacre RC, Berkeley RCW, Mitchell R (1991) Characterization of exopolymers of aquatic bacteria by pyrolysis-mass spectrometry. Appl Environ Microbiol 57: 1595-1601

Fowler SW, Knauer GA (1986) Role of large particles in the transport of elements and organic compounds through the oceanic water column. Prog Oceanogr 16: 147-194

Gherna R, Woese CR (1992) A partial phylogenetic analysis of the 'flavobacter-bacteroides' phylum: basis for taxonomic restructuring. Syst Appl Microbiol 15: 513-521

Gosink JJ, Woese CR, Staley JT (1998) Polaribactergen. nov., with three new species, $P$. irgensii sp. nov., $P$. franzmannii sp. nov. and $P$. filamentus sp. nov., gas vacuolate polar marine bacteria of the Cytophaga-FlavobacteriumBacteroides group and reclassification of 'Flectobacillus glomeratus' as Polaribacter glomeratus comb. nov. Int J Syst Bacteriol 48: 223-235

Grossi SM, Kottmeier ST, Sullivan CW (1984) Sea ice microbial communities. III. Seasonal abundance of microalgae and associated bacteria, McMurdo Sound, Antarctica. Microb Ecol 10: 231-242

Grossmann S, Dieckmann GS (1994) Bacterial standing stock, activity and carbon production during formation and growth of sea ice in the Weddell Sea. Appl Environ Microbiol 60: 2746-2753

Guézennec J (2000) The deep-sea hydrothermal vents: a new source of bacterial exopolysaccharides of biotechnological interest? Polymerix 2000. Center Biotechnologies in Brittany, Rennes, France, pp 187-193

Hall TA (1999) BioEdit: a user-friendly biological sequence alignment editor and analysis program for Windows 95/98/NT. Nucl Acids Symp Ser 41: 95-98

Heissenberger A, Herndl GJ (1994) Formation of high molecular weight material by free-living marine bacteria. Mar Ecol-Prog Ser 111: 129-135

Heissenberger A, Leppard GG, Herndl GJ (1996) Ultrastructure of marine snow II. Microbiological considerations. Mar Ecol-Prog Ser 135: 211-308

Hirst CN, Cyr H, Jordan IA (2003) Distribution of Exopolymeric Substances in the Littoral Sediments of an Oligotrophic Lake. Microb Ecol 46: 22-32 
Humphry DR, George A, Black GW, Cummings SP (2001) Flavobacterium frigidarium sp. nov., an aerobic, psychrophilic, xylanolytic and laminarinolytic bacterium from Antarctica. Int J Syst Evol Micro 51: 1235-1243

Junge K, Eicken H, Deming JW (2004) Bacterial Activity at -2 to $-20^{\circ} \mathrm{C}$ in Arctic Wintertime Sea Ice. Appl Environ Microbiol 70: 550-557

Kamerling JP, Gerwig GJ, Vliegenthart JFG, Clamp JR (1975) Characterization by gas-liquid chromatography-mass spectrometry and proton-magnetic-resonance spectroscopy of pertrimethylsilyl methyl glycosides obtained in the methanolysis of glycoproteins and glycopeptides. Biochem J 151: 491-495

Kenne L, Lindberg B (1983) Bacterial Polysaccharides. In: Aspinall GO (ed) The Polysaccharides. Academic Press, New York, pp 287-363

Kennedy AFD, Sutherland IW (1987) Analysis of bacterial exopolysaccharides. Biotechnol Appl Biochem 9: 12-19

Kiorboe T (2001) Formation and fate of marine snow: small-scale processes with large scale implications. Sci Mar 65: 57-71

Krembs C, Eicken H, Junge K, Deming JW (2002) High concentrations of exopolymeric substances in Arctic winter sea ice: implications for the polar ocean carbon cycle and cryoprotection of diatoms. Deep-Sea Res Pt I 49: 2163-2181

Krembs C, Engel A (2001) Abundance and variability of microorganisms and transparent exopolymer particles across ice-water interface of melting firstyear sea ice in the Laptev Sea (Arctic). Mar Biol 138: 173-185

Leppard GG (1995) The characterization of algal and microbial mucilages and their aggregates in aquatic ecosystems. Sci Total Environ 165: 103-131

Leppard GG, Heissenberger A, Herndl GJ (1996) Ultrastructure of marine snow. I. Transmission electron microscopy methodology. Mar Ecol-Prog Ser 135: $289-298$

Lijour Y, Gentric E, Deslandes E, Guézennec J (1994) Estimation of the sulfate content of hydrothermal vent bacterial polysaccharides by Fourier Transform Infrared Spectroscopy. Anal Biochem 220: 244-248

Loaec M, Olier R, Guézennec J (1998) Chelating properties of bacterial exopolysaccharides from deep-sea hydrothermal vents. Carbohydr Polym 35: $65-70$

Logan BE, Hunt JR (1987) Advantages to microbes of growth in permeable aggregates in marine systems. Limnol Oceanogr 32: 1034-1048

Lowry OH, Rosebrough NJ, Farr AL, Randall RJ (1951) Protein measurement with the Folin-phenol reagent. J Biol Chem 193: 265-274 
Mancuso Nichols C, Garon S, Bowman JP, Raguénès G, Guézennec J (2004) Production of exopolysaccharides by Antarctic marine bacterial isolates. J Appl Microbiol 96: 1057-1066

Montreuil J, Bouquelet S, Debray H, Fournet B, Spik G, Strecker G (1986) Glycoproteins. In: Chaplin MF, Kennedy JF (eds) Carbohydrate analysis, a practical approach. IRL Press, Oxford, pp 143-204

Mueller-Niklas G, Schuster S, Kaltenboeck E, Herndl GJ (1994) Organic content and bacterial metabolism in amorphous aggregations of the northern Adriatic Sea. Limnol Oceanogr 39: 58-68

Nichols PD, Guckert JB, White DC (1986) Determination of monounsaturated fatty acid double-bond position and geometry for microbial monocultures and complex consortia by capillary GC-MS of their dimethyl disulfide adducts. J Microbiol Meth 5: 49-55

Rimington C (1931) The carbohydrate complex of the serum proteins. II : Improved method for isolation and redetermination of structure, isolation of glucosaminodimannose from proteins of ox blood. Biochem J 25: 1062-1071

Rougeaux H, Pichon R, Kervarec N, Raguénès GHC, Guézennec JG (1996) Novel bacterial exopolysaccharides from deep-sea hydrothermal vents. Carbohydr Polym 31: 237-242

Sasser M (1990) Identification of bacteria by gas chromatography of cellular fatty acids. Microbial ID, 101, Newark, DE, USA

Scharek R, Vanleeuwe MA, Debaar HJW (1997) Responses of southern ocean phytoplankton to the addition of trace metals. Deep-Sea Res Pt II 44: 209-227

Selbmann L, Onofri S, Fenice M, Frederico F, Petriuccioli M (2002) Production and structural characterization of the exopolysaccharde of the Antarctic fungus Phoma herbarum CCFEE 5080. Res Microbiol 153: 585-592

Shin HS, Kang ST, Nam SY (2001) Effect of carbohydrate and protein in the EPS on sludge settling characteristics. Water Sci Technol 43: 193-196

Simon M, Glöckner FO, Amann R (1999) Different community structure and temperature optima of heterotrophic picoplankton in various regions of the Southern Ocean. Aquat Microb Ecol 18: 275-284

Staley JT, Gosink JJ (1999) Poles apart: Biodiversity and biogeography of sea ice bacteria. Annu Rev Microbiol 53: 189-215

Sullivan CW, Palmisano AC (1984) Sea ice microbial communities: distribution, abundance and diversity of ice bacteria in McMurdo Sound, Antarctica, in 1980. Appl Environ Microbiol 47: 788-795

Sutherland IW (1994) Structure-function relationships in microbial exopolysaccharides. Biotechnol Adv 12: 393-448 
Sutherland IW (1998) Novel and established applications of microbial polysaccharides. Trends Biotechnol 16: 41-46

Vancanneyt M, Segers P, Torck U, Hoste B, Bernardet J-F, Vandamme P, Kersters K (1996) Reclassification of Flavobacterium odoratus (Stutzer 1929) strains to new genus, Myroides, as Myroides oderatus comb. nov. and Myroides odoratimimus sp. nov. Int J Syst Bacteriol 46: 926-932

Wu JF, Boyle E, Sunda W, Wen LS (2001) Soluble and colloidal iron in the oligotrophic North Atlantic and North Pacific. Science 293: 847-849 


\section{FIGURE LEGENDS}

\section{Figure 1.}

Phylogenetic relationship of Antarctic marine bacterial isolates (CAM036, CAM003, CAM015, CAM064, CAM025 and CAM090) in the order Alteromonaadceae based on $16 \mathrm{~S}$ rRNA sequences. The tree was created using maximum-likelihood distanced clustered by the neighbor-joining method. Bar: 0.01 changes per mean nucleotide position. Numbers in parentheses are GenBank nucleotide accession numbers. Outgroup for the analysis was Escherichia coli (J01695).

\section{Figure 2.}

Phylogenetic relationship of Antarctic marine bacterial isolates (CAM030, CAM005 and CAM006) in the family Flavobacteriaceae based on 16S rRNA sequences. The tree was created using maximum-likelihood distanced clustered by the neighbor-joining method. Bar: 0.1 changes per mean nucleotide position. Numbers in parentheses are GenBank nucleotide accession numbers. Outgroup for the analysis was Escherichia coli (J01695).

\section{Figure 3.}

Crude chemical composition of exopolysaccharides produced by Antarctic marine bacteria. Neutral sugars, uronic acids, proteins were determine by colorimetric analysis. Sulfate content was estimated from FT-IR spectra. Amino sugar content was determined by gas chromatography. 


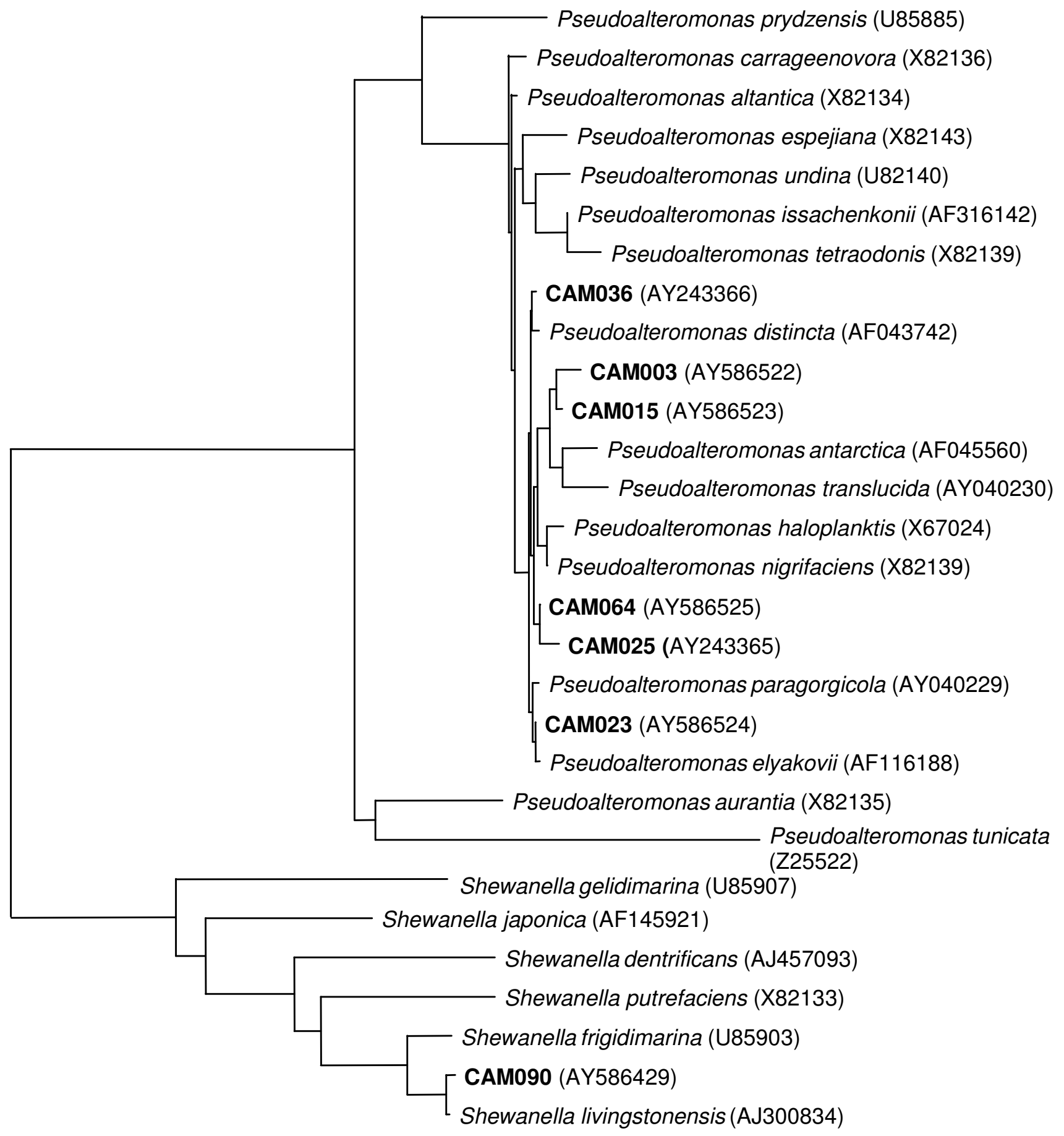

0.01

Figure 1 


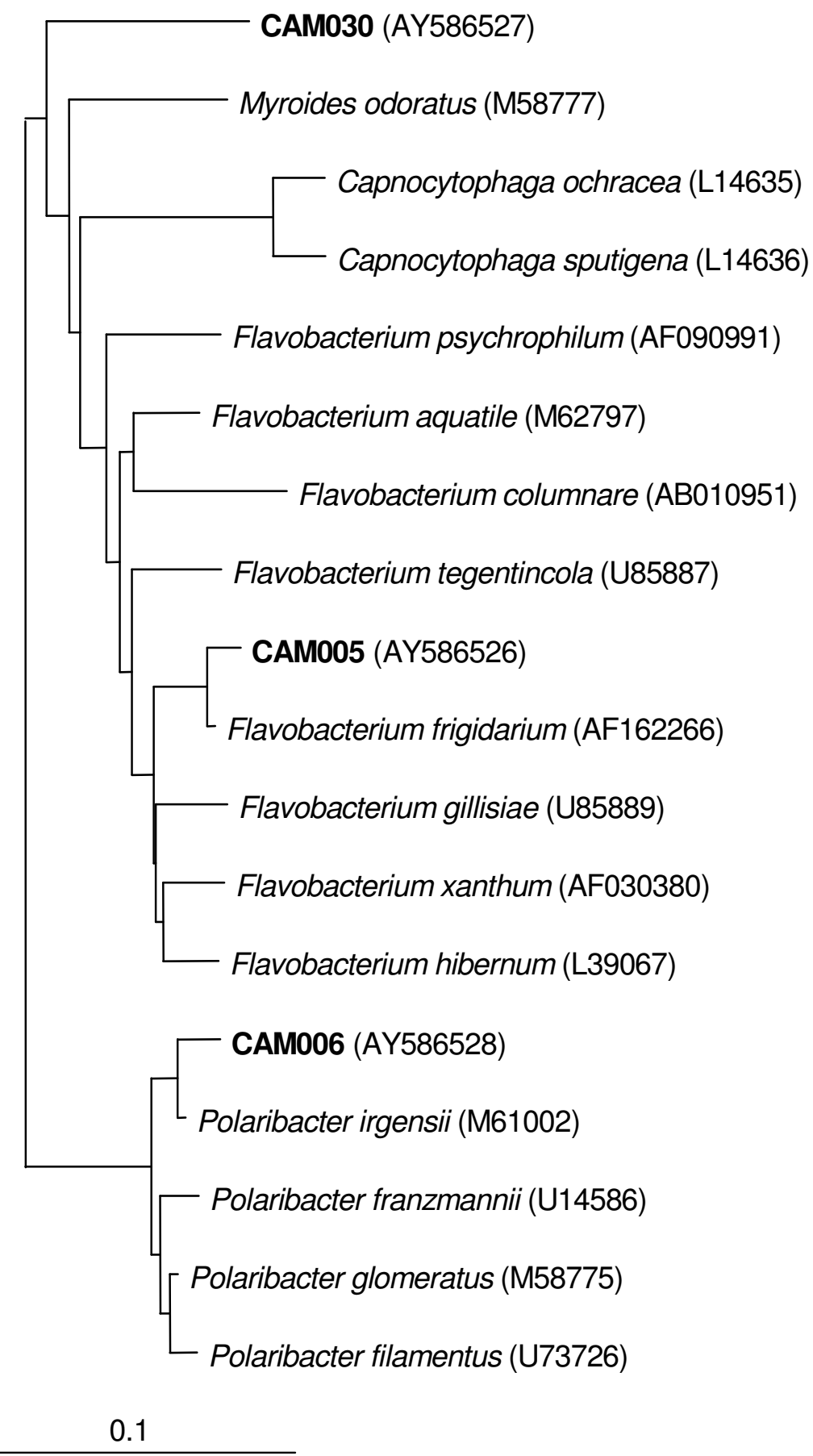

Figure 2 


\section{Crude chemical composition of EPS produced by Antarctic marine bacteria}

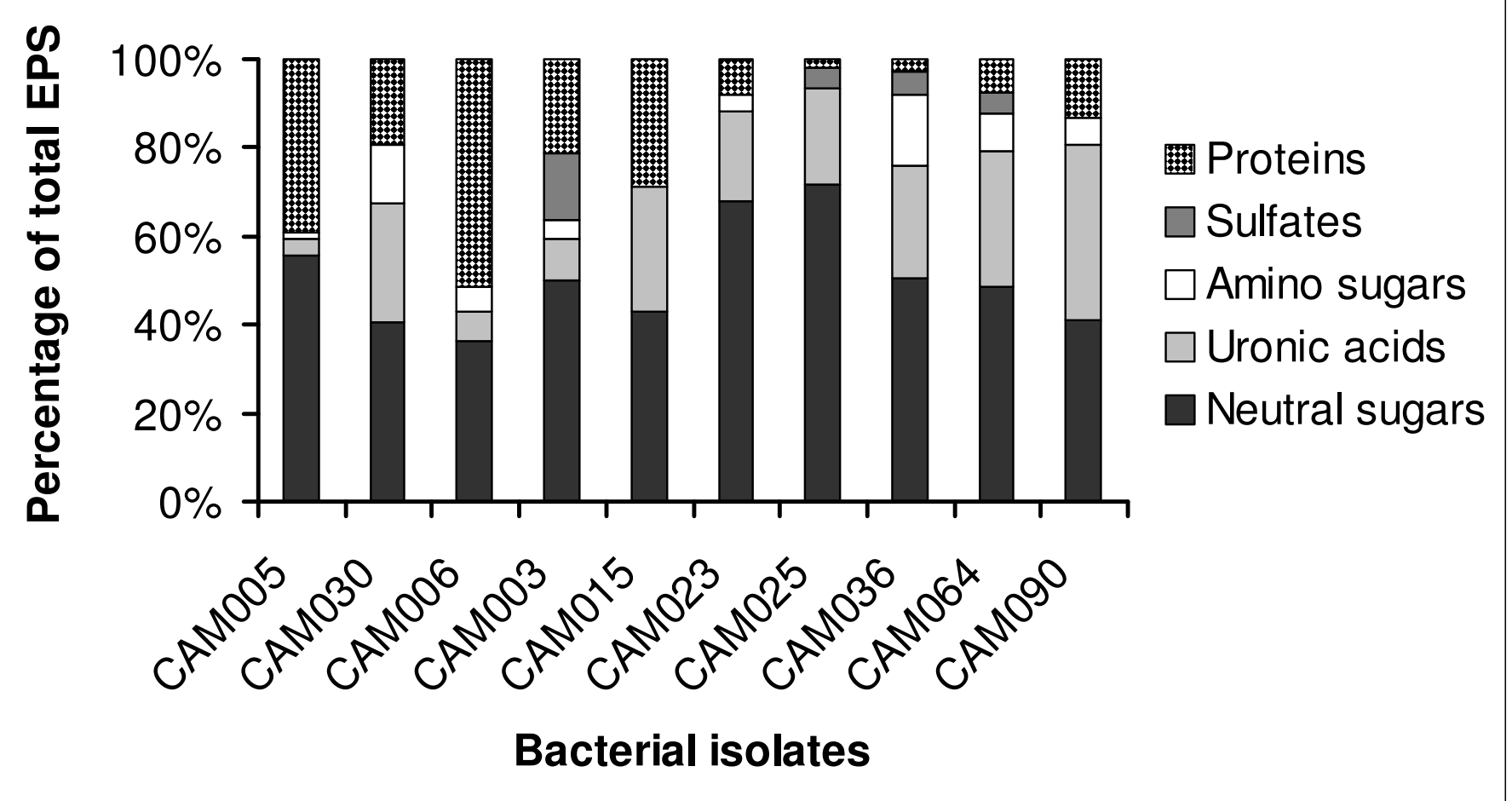


Table 1. Source information for exopolysaccharide producing Antarctic marine bacterial isolates

\begin{tabular}{|c|c|c|c|c|c|}
\hline Isolate & Position of sample site & Type of source material & $\begin{array}{c}\text { Size fraction of source } \\
\text { material }\end{array}$ & $\begin{array}{c}\text { Treatment prior to } \\
\text { culturing }\end{array}$ & Taxonomic grouping \\
\hline CAM005 & $66^{\circ} 38^{\prime} 10^{\prime \prime S}, 141^{\circ} 4276^{\prime \prime} \mathrm{E}$ & melted fast ice & $>0.8 \mu \mathrm{m}$ & filtering/enrichment & Favobacterium sp. \\
\hline CAM030 & $65^{\circ} 32^{\prime} 06^{\prime \prime} \mathrm{S}, 143^{\circ} 10^{\prime} 16^{\prime \prime} \mathrm{E}$ & plankton tow & $>20 \mu \mathrm{m}$ & none & Favobacteriaceae \\
\hline CAM006 & $65^{\circ} 32^{\prime} 06^{\prime \prime} \mathrm{S}, 143^{\circ} 10^{\prime} 16^{\prime \prime} \mathrm{E}$ & plankton tow & $>20 \mu \mathrm{m}$ & none & Polaribacter sp. \\
\hline CAM003 & $63^{\circ} 52^{\prime} 41^{\prime \prime S}, 139^{\circ} 41^{\prime} 47^{\prime \prime E}$ & melted pack ice & $>0.8 \mu \mathrm{m}$ & filtering/enrichment & Pseudoaltermonas sp. \\
\hline CAM015 & $65^{\circ} 03$ "S, $142^{\circ} 31^{\prime} 61^{\prime \prime E}$ & melted fast ice & $<0.8 \mu \mathrm{m}$ & filtering/enrichment & Pseudoaltermonas sp. \\
\hline СAM023 & $65^{\circ} 32^{\prime} 06^{\prime \prime} \mathrm{S}, 143^{\circ} 10^{\prime} 16^{\prime \prime} \mathrm{E}$ & plankton tow & $>20 \mu \mathrm{m}$ & none & Pseudoaltermonas sp. \\
\hline CAM025 & $63^{\circ} 52^{\prime} 04$ "S, $139^{\circ} 41^{\prime} 47^{\prime \prime E}$ & melted pack ice & $<0.8 \mu \mathrm{m}$ & filtering/enrichment & Pseudoaltermonas sp. \\
\hline CAM036 & $65^{\circ} 32^{\prime} 06^{\prime \prime} \mathrm{S}, 143^{\circ} 10^{\prime} 16^{\prime \prime} \mathrm{E}$ & plankton tow & $>20 \mu \mathrm{m}$ & none & Pseudoaltermonas sp. \\
\hline CAM064 & $65^{\circ} 03^{\prime \prime S}, 142^{\circ} 31^{\prime} 61^{\prime \prime E}$ & melted fast ice & $>0.8 \mu \mathrm{m}$ & filtering/enrichment & Pseudoaltermonas sp. \\
\hline CAM090 & $66^{\circ} 38^{\prime} 10^{\prime \prime S}, 141^{\circ} 42^{\prime} 76^{\prime \prime E}$ & melted fast ice & $>0.8 \mu \mathrm{m}$ & filtering/enrichment & Shewanella sp. \\
\hline
\end{tabular}




\begin{tabular}{|c|c|c|c|c|c|c|c|c|c|c|}
\hline \multirow[b]{2}{*}{ Fatty Acid } & \multicolumn{10}{|c|}{ Isolates } \\
\hline & CAM005 & CAM030 & CAM006 & CAM003 & CAM015 & CAM023 & CAM025 & CAM036 & CAM064 & CAM090 \\
\hline i13:0 & 1.0 & $\operatorname{tr}^{*}$ & 3.0 & 3.6 & & & & & & 18.9 \\
\hline $13: 0$ & $\operatorname{tr}$ & $\operatorname{tr}$ & 1.6 & 3.1 & $\operatorname{tr}$ & $\operatorname{tr}$ & $\operatorname{tr}$ & $\operatorname{tr}$ & 3.4 & 4.0 \\
\hline$\beta-\mathrm{OH} 12: 0$ & & & & 1.6 & 2.0 & 1.7 & 1.5 & 2.3 & 2.1 & $\operatorname{tr}$ \\
\hline $14: 0$ & $\operatorname{tr}$ & $\operatorname{tr}$ & $\operatorname{tr}$ & 1.1 & $\operatorname{tr}$ & $\operatorname{tr}$ & $\operatorname{tr}$ & $\operatorname{tr}$ & $\operatorname{tr}$ & 2.1 \\
\hline$\beta-\mathrm{OH} 12: 0$ & & & & 3.1 & 4.3 & 3.3 & 3.5 & 6.5 & 6.5 & 2.0 \\
\hline i $15: 1 \omega 10 c$ & 9.3 & 21.9 & 13.7 & & & 2.4 & 1.9 & 2.1 & 3.5 & \\
\hline 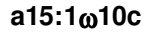 & 1.7 & 7.9 & $\operatorname{tr}$ & & & & & & & \\
\hline i15:0 & 9.6 & 18.8 & 14.9 & & & & & & & 5.0 \\
\hline a15:0 & 3.9 & 4.0 & 1.1 & & & & & & & \\
\hline$\alpha-\mathrm{OHi13:0}$ & & & 2.4 & & & & & & & \\
\hline $15: 1 \omega 8 c$ & & & & 3.5 & 4.5 & 3.9 & 4.0 & 3.3 & 2.5 & 5.3 \\
\hline $15: 1 \omega 6 c$ & & & 3.7 & & & & & & & \\
\hline$\alpha$-OHi1 3:1 & 2.5 & 1.7 & & & & & & & & \\
\hline $15: 1 \omega 8 t$ & & & & 1.7 & $\operatorname{tr}$ & 1.1 & 1.5 & 1.8 & 1.0 & $\operatorname{tr}$ \\
\hline $15: 1 w 6 t$ & 1.8 & 2.1 & & & & & & & & \\
\hline 15:0 & 3.2 & 7.3 & 4.0 & 4.6 & 4.2 & 3.7 & 4.7 & 3.3 & 3.7 & 3.2 \\
\hline$\beta-\mathrm{OH} 13: 0$ & $\operatorname{tr}$ & $\operatorname{tr}$ & $\operatorname{tr}$ & $\operatorname{tr}$ & 2.0 & 2.2 & 2.2 & 3.3 & 2.6 & 1.7 \\
\hline 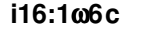 & 2.9 & $\operatorname{tr}$ & $\operatorname{tr}$ & & & & & & & \\
\hline i16:0 & 4.0 & tr & & 1.1 & tr & 1.2 & $\operatorname{tr}$ & tr & $\operatorname{tr}$ & \\
\hline $16: 1 \omega 9 c$ & 1.4 & & & 1.0 & $\operatorname{tr}$ & tr & $\operatorname{tr}$ & $\operatorname{tr}$ & $\operatorname{tr}$ & 1.2 \\
\hline $16: 1 \omega 7 c$ & 5.3 & 1.3 & 8.3 & 31.1 & 26.3 & 18.8 & 21.4 & 26.2 & 21.7 & 38.2 \\
\hline $16: 1 \omega 7 t$ & & & 1.7 & 7.8 & 3.8 & 8.6 & 7.5 & 6.7 & 7.9 & \\
\hline$\beta-\mathrm{OH} 14: 1$ & & & & & & & & & $\operatorname{tr}$ & 3.5 \\
\hline $16: 0$ & 1.5 & 1.2 & $\operatorname{tr}$ & 9.1 & 9.2 & 7.6 & 7.5 & 7.3 & 8.6 & 9.0 \\
\hline$\beta-O H$ 14:0 & & & & & & & & & & 2.0 \\
\hline$\beta-\mathrm{OH}$ i15:0 & 12.2 & 10.4 & 20.6 & & & & & & & \\
\hline$\alpha-\mathrm{OH}$ i 15:0 & & 6.8 & 14.4 & & & & & & & \\
\hline$\alpha-\mathrm{OH}$ a 15:0 & 2.0 & 1.7 & 2.1 & & & & & & & \\
\hline $17: 1 \omega 8 c$ & & & & 20.5 & 26.9 & 29.2 & 29.3 & 24.2 & 21.0 & 10.2 \\
\hline $17: 1 \omega 8 t$ & & & & 3.8 & 4.4 & 6.5 & 6.8 & 4.1 & 4.1 & 2.2 \\
\hline $17: 0$ & $\operatorname{tr}$ & & & 4.5 & 6.5 & 5.7 & 4.8 & 5.6 & 5.1 & 3.2 \\
\hline$\beta-O H$ 15:0 & 1.5 & 3.8 & 3.1 & & & & & & & \\
\hline$\alpha-\mathrm{OH} \mathrm{15:0}$ & & & 1.4 & & & & & & & \\
\hline$\alpha-\mathrm{OH}$ i $16: 0$ & 11.4 & 4.4 & 4.4 & & & & & & & \\
\hline $18: 1 \omega 9 c$ & $\operatorname{tr}$ & & & $\operatorname{tr}$ & $\operatorname{tr}$ & $\operatorname{tr}$ & $\operatorname{tr}$ & & $\operatorname{tr}$ & 1.7 \\
\hline $18: 1 \omega 7 c$ & 1.3 & $\operatorname{tr}$ & & 5.4 & 5.8 & 4.2 & 3.5 & 3.3 & 6.3 & 8.6 \\
\hline $\begin{array}{l}\beta-O H \text { 16:0 } \\
\beta-O H \text { i17:0 }\end{array}$ & $\begin{array}{c}7.3 \\
12.9\end{array}$ & $\begin{array}{l}\operatorname{tr} \\
4.4\end{array}$ & $\begin{array}{l}\operatorname{tr} \\
1.2\end{array}$ & & & & & & & \\
\hline
\end{tabular}

$\Lambda$ listed in order of retention time

*tr : $<1 \%$ total area

Also present in trace amounts in the following strains:

CAM005: i14:0, a17:1, i17:1, $\beta$-OH 17:1; CAM030: a17:1, i17:1, $\beta$-OH i17:1, $\beta-\mathrm{OH}$ 17:1;

CAM006: i14:0, a-OH 13:0, b-OH i17:1; CAM003: i17:0, 18:0; CAM015: i17:0, 18:0; CAM023:i17:0, 18:0;

CAM064: 18:0; CAM090: i14:0, 18:0 
Table 3. EPS mono saccharides from ten Antarct marine bacterial isolates reported at percentage of total sugars

\begin{tabular}{|c|c|c|c|c|c|c|c|c|c|c|}
\hline \multirow[b]{2}{*}{ Monosaccharides } & \multicolumn{9}{|c|}{ Isolates } & \multirow[b]{2}{*}{ CAM090 } \\
\hline & CAM005 & CAM030 & CAM006 & CAM003 & CAM015 & CAM023 & CAM025 & CAM036 & CAM064 & \\
\hline Ara* & 5 & 6 & 2 & 4 & 10 & 12 & 3 & 3 & 4 & 13 \\
\hline Rib & & & & 2 & & & 1 & & & \\
\hline Rha & & 1 & & 6 & 6 & & 5 & & & 2 \\
\hline Fuc & & & 11 & 29 & & & 1 & & & \\
\hline Xyl & & 2 & & & 1 & & & & & 2 \\
\hline Man & 74 & 48 & 33 & 40 & 36 & 2 & 1 & 24 & 64 & 41 \\
\hline Gal & 3 & 4 & 38 & 0 & 4 & 1 & 5 & 1 & 4 & 5 \\
\hline GIc & 8 & 9 & 4 & 16 & 38 & 75 & 52 & 26 & 8 & 10 \\
\hline Gal A & & 2 & & & & 5 & 30 & 30 & & \\
\hline Glc A & 8 & 10 & 6 & 1 & 3 & 3 & & & 6 & 20 \\
\hline N-A Gal & & 10 & 1 & 1 & 3 & 2 & 1 & 14 & 11 & 7 \\
\hline N-A Glc & 1 & 8 & 4 & 1 & & & & 1 & 2 & \\
\hline
\end{tabular}

*Ara indicates arabinose; Rib, ribose; Rha, rhamnose; Fuc, fucose; Xyl, xylose; Man, mannose; Gal, galactose; Glc, glucose; Gal A, galacuronic acid; Glc A, glucuronic acid; N-A Gal, N-acetyl-galactosamine and N-A Glc, N-acetyl-glucosamine. 
Table 4. Molecular weights of exopolysaccharides produced by Antarctic marine bacteria determined by Size Exclusion Chromatography

\begin{tabular}{ccc}
\hline Isolate & $\begin{array}{c}\text { Molecular weight } \\
\text { ( MDaltons) }\end{array}$ & $\begin{array}{c}\text { I } \\
\text { (polydispers ity) }\end{array}$ \\
\hline CAM005 & 1.81 & 1.249 \\
CAM030 & 0.19 & 1.891 \\
CAM006 & 2.10 & 1.224 \\
CAM003 & 1.80 & 2.075 \\
CAM015 & 2.80 & 1.143 \\
CAM023 & 1.80 & 1.381 \\
CAM025 & 5.70 & 2.496 \\
CAM036 & 1.70 & 1.616 \\
CAM064 & 0.10 & 1.172 \\
CAM090 & 0.08 & 1.326 \\
\hline
\end{tabular}

